\title{
Functional implications of changes in seagrass species composition in two shallow coastal lagoons
}

\author{
Bart Christiaen $^{1, *}$, John C. Lehrter ${ }^{2}$, Joshua Goff ${ }^{3}$, Just Cebrian ${ }^{3,4}$ \\ ${ }^{1}$ Washington Department of Natural Resources, Olympia, WA 98504, USA \\ ${ }^{2}$ US EPA, Gulf Ecology Division, Gulf Breeze, FL 32561, USA \\ ${ }^{3}$ Dauphin Island Sea Lab, Dauphin Island, AL 36528, USA \\ ${ }^{4}$ University of South Alabama, Mobile, AL 36608, USA
}

\begin{abstract}
While the consequences of losing seagrass meadows are well known, there is less information on the functional implications of changes in seagrass species composition. In this study, we use data from a long-term monitoring project in shallow lagoons on the Florida Gulf Coast to assess changes in the functional attributes of seagrass beds during a shift in seagrass species composition. We compare seagrass beds in 2 neighboring lagoons with different trends: one where the composition changed from $100 \%$ Halodule wrightii to a mixed bed with up to $60 \%$ Ruppia maritima, and one where the species composition remained unchanged. Our results indicate that the partial replacement of $H$. wrightii by $R$. maritima did not alter seagrass biomass $\mathrm{m}^{-2}$, detrital biomass $\mathrm{m}^{-2}$, benthic gross primary production, or benthic respiration. However, there was a small positive effect on benthic net primary production. While seagrass biomass $\mathrm{m}^{-2}$ declined at both sites, the emergence of $R$. maritima increased the amount of available habitat through rapid expansion. Overall, our data suggest that shifts between 2 seagrass species with similar morphology, but different ecological strategies, may have little impact on the ecosystem services of seagrass beds in shallow coastal lagoons.
\end{abstract}

KEY WORDS: Ruppia maritima $\cdot$ Halodule wrightii $\cdot$ Seagrass $\cdot$ Species shift $\cdot$ Ecosystem metabolism

\section{INTRODUCTION}

Seagrass beds are important, yet vulnerable components of coastal ecosystems. They provide habitat for a wide range of organisms (Orth et al. 1984), improve water quality by stabilizing sediments (de Boer 2007), and are an important sink for carbon on a global scale (Fourqurean et al. 2012). However, they are sensitive to effects of human activities, such as dredging (Gonzalez-Correa et al. 2005), physical disturbances (Sargent et al. 1995), and the excessive input of nutrients and organic matter from coastal watersheds (Burkholder et al. 2007). During the last century, many coastal regions have experienced large decreases in seagrass cover (Waycott et al. 2009). In addition, there have been several reports of

${ }^{*}$ Corresponding author: bart.christiaen@dnr.wa.gov changes in seagrass species composition throughout the United States (Quammen \& Onuf 1993, Provancha \& Scheidt 2000, Johnson et al. 2003, Cho et al. 2009, Lopez-Calderon et al. 2010, Moore et al. 2013). While the effects of loss of seagrass cover are well described, there is less information on the functional implications of changes in the dominant seagrass species. Biomass, production, and the fate of production can vary significantly between different species (Duarte 1991, Cebrian et al. 1997). As such, it is possible that changes in seagrass species composition can influence the role of seagrass beds in coastal ecosystems.

Halodule wrightii and Ruppia maritima are widespread and abundant along the coast of the Gulf of Mexico. These 2 seagrass species are morphologi-

(C) The authors 2016. Open Access under Creative Commons by Attribution Licence. Use, distribution and reproduction are unrestricted. Authors and original publication must be credited. 
cally similar and often occur in mixed beds, but they have different ecological strategies: $R$. maritima can be classified as a colonizing species, while $H$. wrightii is closer to an opportunistic seagrass species (Kilminster et al. 2015). Colonizing seagrasses have the ability to quickly establish themselves in new areas, but their biomass can fluctuate significantly over time (Pulich 1985, Cho et al. 2009, Kilminster et al. 2015). They quickly reach sexual maturity and produce large amounts of seeds (Bonis et al. 1995). In the case of $R$. maritima, these seeds can remain dormant for extended periods of time (Kantrud 1991) and are able to survive passage through the digestive system of waterfowl and fish, which favors long-distance dispersal of the plants (Agami \& Waisel 1988, Charalambidou et al. 2003).

Opportunistic species also have the ability to colonize new areas, but they tend to form meadows that are more persistent over time and have greater resistance to physiological disturbances than purely colonizing species (Kilminster et al. 2015). H. wrightii is a perennial seagrass that maintains a high level of productivity under a wide variety of light, nutrient, and salinity conditions (Dunton 1996). In the Gulf of Mexico, $H$. wrightii forms overwintering populations that exhibit more consistent growth rates and allocate a larger fraction of total biomass to roots and rhizomes compared to $R$. maritima (Dunton 1990, Kantrud 1991, Antón et al. 2009).

Both $H$. wrightii and $R$. maritima tolerate a wide range of salinities, ranging from nearly fresh water to $>50$ psu (Dunton 1990, Kantrud 1991, Doering et al. 2002, Koch et al. 2007). However, R. maritima is able

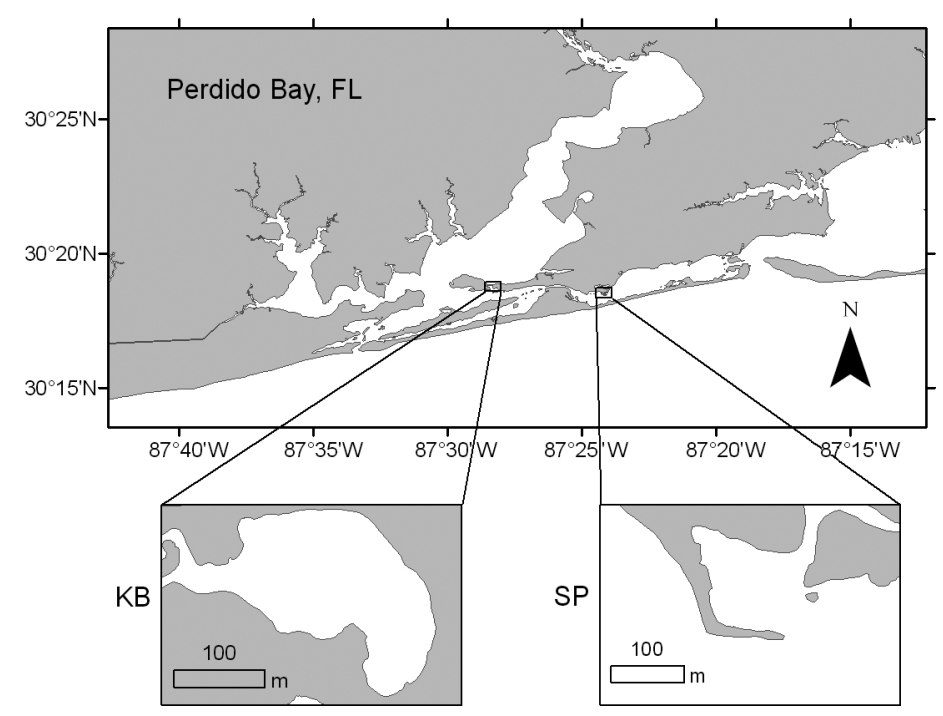

Fig. 1. Location of the 2 study sites, Kees Bayou (KB) and State Park (SP), near Perdido Bay FL, USA to outcompete $H$. wrightii when salinity is low (Provancha \& Scheidt 2000). When both species are present along an estuarine gradient, $R$. maritima will often dominate in brackish areas, while $H$. wrightii is more abundant at higher salinities (Montague \& Ley 1993, Adair et al. 1994).

Many studies have documented changes in species composition due to disturbances in these tropical New World seagrass beds. Grazing, variability in freshwater input, and modified nutrient regimes have caused changes in seagrass species composition in Laguna Madre (Quammen \& Onuf 1993), Lake Pontchartrain (Cho \& Poirrier 2005), and the Florida Keys (Peterson et al. 2002, Fourqurean et al. 1995, Herbert \& Fourqurean 2008, Herbert et al. 2011). However, there are relatively few studies that directly measured changes in functional attributes of seagrass beds during a shift from one dominant seagrass species to another (Peterson et al. 2002).

In this study, we use long-term data from 2 small coastal lagoons with different trends in seagrass species composition to explore functional consequences of a change from a $H$. wrightii- to a $R$. maritima-dominated seagrass bed. We employ a paired BACI design to test (1) if the change from $H$. wrightii to $R$. maritima did affect aboveground biomass $\mathrm{m}^{-2}$, belowground biomass $\mathrm{m}^{-2}$, and detritus $\mathrm{m}^{-2}$ at our sites and (2) if the change from $H$. wrightii to $R$. maritima did affect benthic net primary production, benthic gross primary production, and benthic respiration at our sites. Testing these hypotheses will provide insights on potential impacts of shifts in the dominant seagrass species on carbon cycling, carbon storage, and habitat characteristics of seagrass beds in shallow coastal lagoons.

\section{MATERIALS AND METHODS}

We used data from a long-term study in 2 shallow coastal embayments, located in the Perdido Bay area, Florida, along the north central Gulf of Mexico: Kees Bayou $\left(30.310^{\circ} \mathrm{N}, 87.469^{\circ} \mathrm{W}\right)$ and State Park $\left(30.308^{\circ} \mathrm{N}, 87.403^{\circ} \mathrm{W}\right)$. These 2 sites are relatively close to each other and experience similar weather patterns (Fig. 1). State Park is the site with the least amount of human disturbance. This shallow lagoon is entirely surrounded by salt marsh and maritime forest, with no residential development adjacent to its shoreline or in its watershed. State Park is on average $0.4 \mathrm{~m}$ deep, has a surface area of $15600 \mathrm{~m}^{2}$, and is approximately $50 \%$ covered with Halodule wrightii. This site is connected to both Big Lagoon 
and a brackish inland lake surrounded by wetlands. Kees Bayou has residential development on the northern and the eastern sides of the lagoon, while the southern and western sides are bordered by salt marsh. Kees Bayou is on average $0.47 \mathrm{~m}$ deep, has a surface area of $27400 \mathrm{~m}^{2}$, and is connected to Lower Perdido Bay by a small channel that passes through a nearby lagoon. At the start of our project, in 2000, $5 \%$ of Kees Bayou was covered by a small bed of $H$. wrightii (Stutes et al. 2007). By 2012, up to $48 \%$ of the bottom was covered by a mixed bed of $H$. wrightii and Ruppia maritima. Kees Bayou is more enclosed than State Park and is more affected by freshwater inflow due to its closer proximity to Perdido Bay.

State Park and Kees Bayou were sampled 4 to 5 times per year from September 2000 to January 2012. For each sampling round, both sites were sampled within a $10 \mathrm{~d}$ interval on days with $<10 \%$ cloud cover. At each site, 5 cores $(15 \mathrm{~cm}$ diameter, $10 \mathrm{~cm}$ deep) were randomly collected in the seagrass bed (Fig. 2). The cores were sieved through a $0.5 \mathrm{~mm}$ mesh, stored on ice, and transported to the lab for further analysis. In each core, shoots of $R$. maritima and $H$. wrightii were counted to determine shoot density for both seagrass species. Living plant material (rhizomes with at least 1 green shoot attached) was sorted into aboveground biomass and belowground biomass. Dead plant material was counted as detritus. The detrital fraction is likely an overestimation because it contains pieces of rhizome and shoots that were broken off when they were cut with the corer. Each fraction was measured as ash-free dry weight $\mathrm{m}^{-2}$. Temperature, salinity, and dissolved oxygen were measured using handheld units (YSI-85 or Hach HQ40d). Light inten-

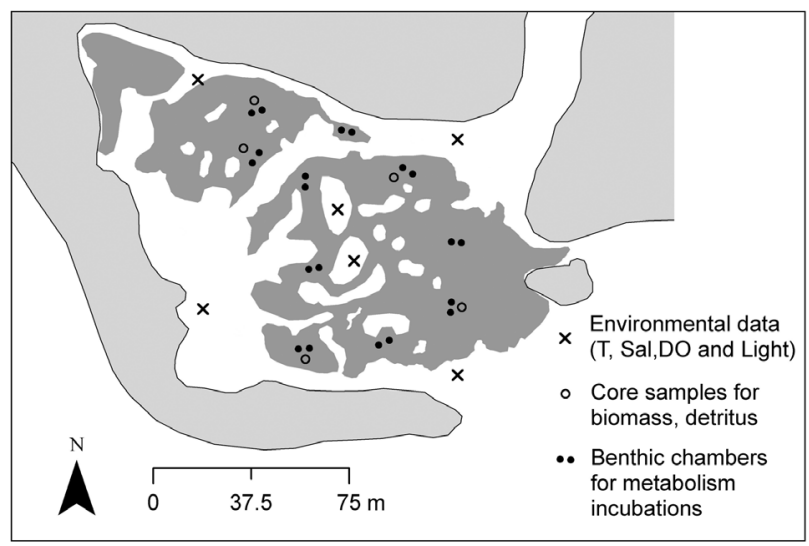

Fig. 2. Illustration of a sample event in State Park lagoon in 2012. When a site was sampled, 10 pairs of benthic incubation chambers were placed at random locations inside the seagrass bed, 5 core samples were taken haphazardly, and environmental data was collected at 6 stations throughout the site. T: temperature; Sal: salinity; DO: dissolved oxygen sity in the air, just beneath the surface, and on the bottom was measured using a pair of Licor-193 with spherical bulbs and a data-logger.

From December 2001 to September 2003 and from January 2005 to January 2012, we measured daytime community metabolism using short ( 3 to $5 \mathrm{~h}$ ) field incubations with clear/dark BOD bottles and benthic chambers (Stutes et al. 2007, Cebrian et al. 2008, 2009, Antón et al. 2009, 2011). For each site visit, 10 pairs of clear and dark benthic incubation chambers and 5 sets of clear and dark BOD bottles were randomly placed within the seagrass beds and incubated through solar noon (Fig. 2). We measured oxygen concentrations at the start and the end of the bottle incubations using a handheld oxygen meter (WTW OXI 197 or Hack LDO). Benthic chambers were measured at the end of the incubation by extracting water from the center of each chamber though a sample port using a $60 \mathrm{ml}$ syringe with an attached tube. The water was carefully transferred to a small BOD bottle and measured using the handheld oxygen meters. The average oxygen concentrations measured in the bottles immediately after filling were used as the initial oxygen concentration in the benthic chambers. We used the mean change in oxygen concentration over time from the chamber incubations to calculate benthic daytime net primary production (BNPP) and benthic daytime community respiration (BR), based on Eqs. (1) \& (2). The mean change in oxygen concentration for the clear and dark bottles (Eqs. 3 \& 4) was subtracted from the chamber values to correct for the head-volume enclosed in the chambers.

$$
\begin{gathered}
\mathrm{BNPP}=V\left(\left[F_{\mathrm{c}}-I\right] / \mathrm{dt}-P_{\mathrm{c}}\right) / A \\
\mathrm{BR}=V\left(\left[F_{\mathrm{d}}-I\right] / \mathrm{dt}-P_{\mathrm{d}}\right) / A \\
P_{\mathrm{c}}=\text { average }\left(\left[F B_{\mathrm{c}}-I B_{\mathrm{c}}\right] / \mathrm{dt}\right) \\
P_{\mathrm{d}}=\text { average }\left(\left[F B_{\mathrm{d}}-I B_{\mathrm{d}}\right] / \mathrm{dt}\right)
\end{gathered}
$$

In Eqs. (1) \& (2), $V$ is the volume of water enclosed in the chambers $(1), F_{\mathrm{c}}$ is the final oxygen concentration in the clear chamber incubations $\left(\mathrm{mg} \mathrm{l}^{-1}\right), F_{\mathrm{d}}$ is the final oxygen concentration in the dark chamber incubations $\left(\mathrm{mg} \mathrm{l}^{-1}\right), I$ is the initial oxygen concentration $\left(\mathrm{mg} \mathrm{l}^{-1}\right), A$ is the surface enclosed by the chambers $\left(\mathrm{m}^{2}\right), P_{\mathrm{c}}$ is the mean change in oxygen concentrations during the clear bottle incubations $\left(\mathrm{mg} \mathrm{l} \mathrm{h}^{-1}\right)$, and $P_{\mathrm{d}}$ is the mean change in oxygen concentrations during the dark bottle incubations $\left(\mathrm{mg} \mathrm{l} \mathrm{h}^{-1}\right)$. In Eqs. (3) \& (4), $F B_{\mathrm{c}}$ is the final oxygen concentration in the clear bottles $\left(\mathrm{mg} \mathrm{l}^{-1}\right), F B_{\mathrm{d}}$ is the final oxygen concentration in the dark bottles $\left(\mathrm{mg} \mathrm{l}^{-1}\right), I B_{\mathrm{c}}$ is the initial oxygen concentration in the clear bottles $\left(\mathrm{mg} \mathrm{l}^{-1}\right)$, and $I B_{\mathrm{d}}$ is the initial oxygen concentrations in the 
dark bottles $\left(\mathrm{mg} \mathrm{l}^{-1}\right)$. Daytime gross primary production (BGPP) was calculated as the sum of BNPP and the absolute value of BR for each pair of chambers.

The percentage of seagrass cover in each of the lagoons was assessed by analyzing aerial and satellite pictures with ArcMap 10. Pictures were georeferenced, and the shapes of the lagoons and seagrass patches were digitized as polygons. In 2011, measurements were ground-truthed by tracing the contour of the seagrass patches in both lagoons using a real-time kinematic global positioning system (RTK). The relative size of the seagrass patches was calculated as the quotient of the areal extent of the seagrass patches and the size of each lagoon.

To address our main questions, we used an approach similar to a paired BACI design (StewartOaten et al. 1986): we calculated the differences in average biomass and metabolism between the 2 sites for each sample event and compared the means of these differences before and after the emergence of $R$. maritima in Kees Bayou using Welch's 2-sample $t$ tests (Stewart-Oaten et al. 1986). All data were tested for additivity, normality, and equality of variance. If necessary, data were log-transformed to meet the assumption of additivity (Stewart-Oaten et al. 1986). All statistics were calculated using Minitab 14.

\section{RESULTS}

The environmental characteristics of the water column showed significant variability over time in both State Park and Kees Bayou. Temperature (range: 6.45 to $33.75^{\circ} \mathrm{C}$ ) and salinity (range: 3.24 to 31.59 ) varied significantly over seasonal timescales (Fig. 3). Salinity showed a large variability over inter-annual timescales, as it was related to the mean river discharge into Perdido Bay (Fig. 3). There was no difference in temperature and dissolved oxygen between State Park and Kees Bayou. However, salinity was significantly lower in Kees Bayou (19.96 \pm 0.66 ; mean $\pm \mathrm{SE})$ than in State Park $(23.10 \pm 0.61$, paired $t$-test: $t=-6.56, \mathrm{p}<0.001)$, which is likely due to its closer proximity to river discharge. Dissolved oxygen concentrations also changed on a seasonal timescale (range: 3.68 to $13.19 \mathrm{mg} \mathrm{l}^{-1}$ ). Daily changes in dissolved oxygen were more pronounced during summer, when water temperatures were high (range: 0.41 to $9.37 \mathrm{mg} \mathrm{l}^{-1}$ in Kees Bayou during July 2011, measured during a short-term deployment of a YSI6600).

From 2004 to 2012, the seagrass bed in Kees Bayou underwent marked changes (Fig. 4). The size of the seagrass bed increased, from approximately $10 \%$
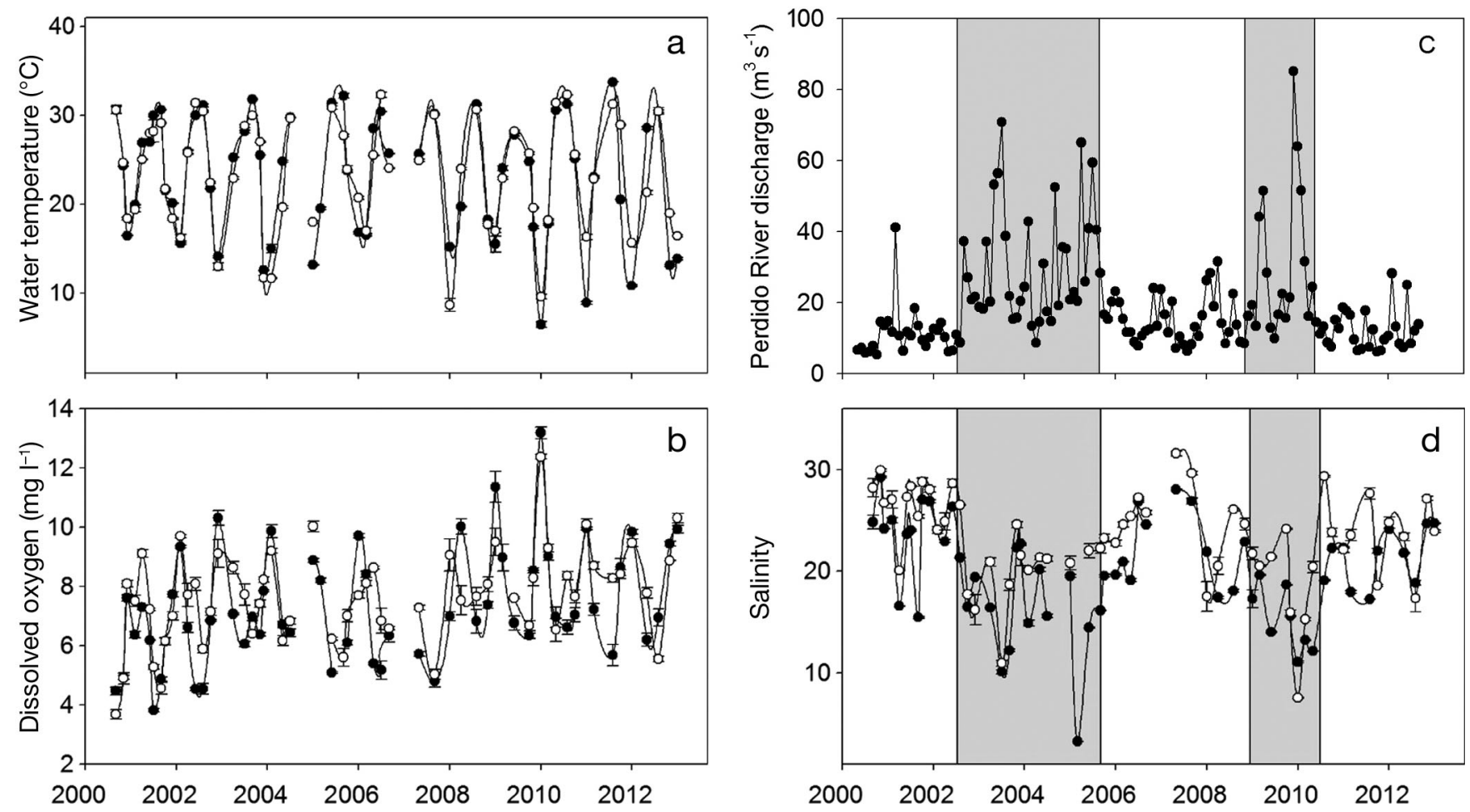

Fig. 3. (a) Temperature of the water column and (b) dissolved oxygen in State Park (white) and Kees Bayou (black). (c) River discharge from the Perdido River. (d) Salinity in State Park (white) and Kees Bayou (black). Grey bands indicate periods of high river discharge 


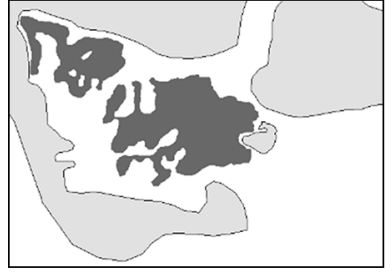

Dec $2004-45.8 \%$

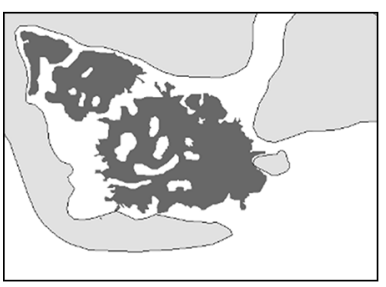

Dec $2010-57.0 \%$

Size of the seagrass bed in State Park

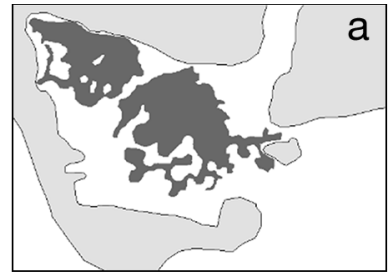

April $2007-43.1 \%$

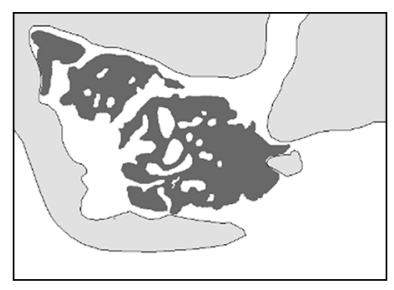

$\operatorname{Jan} 2012-53.1 \%$

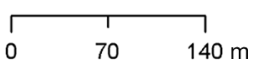

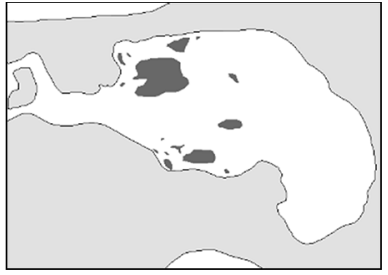

Dec $2004-10.7 \%$

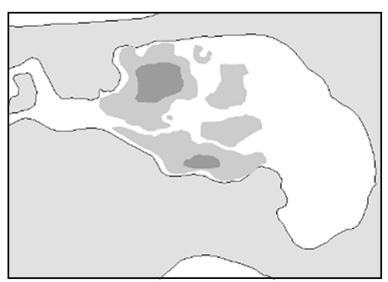

Dec $2010-33.5 \%$

Size of the seagrass bed in Kees Bayou

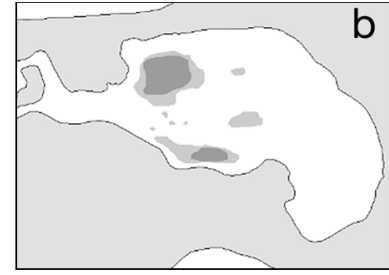

April $2007-12.7 \%$

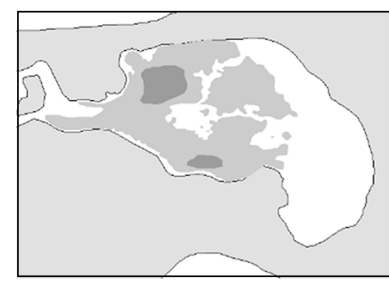

$\operatorname{Jan} 2012-48.2 \%$

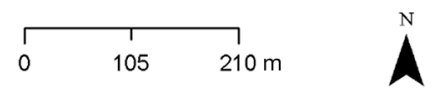

Fig. 4. (a) The seagrass bed in State Park was relatively stable. (b) The seagrass bed in Kees Bayou expanded over time. Darker colors indicate seagrass patches dominated by $H$. wrightii, lighter colors indicate patches dominated by $R$. maritima

cover in December 2004 to $48 \%$ cover in January 2012. During that time, the species composition changed from a homogeneous bed of Halodule wrightii to a mixed bed dominated by Ruppia maritima (up to $60 \% R$. maritima; Fig. 5). The seagrass bed in State Park was more stable. The size of the seagrass bed remained more or less constant at $50 \%$ cover (Fig. 4), and the species composition remained the same (almost $100 \%$ H. wrightii; Fig. 5). The change in species cover occurred after a period of low salinity in Kees Bayou and high river discharge into Perdido Bay (Fig. 3).

Fig. 6 illustrates that average aboveground and belowground biomass $\mathrm{m}^{-2}$ was higher in State Park compared to Kees Bayou but that average biomass $\mathrm{m}^{-2}$ declined in both sites (Table 1). These trends were mirrored by the averaged metabolism data (Fig. 6). The $t$-tests comparing paired differences between the sites before and after January 2006 indicate that aboveground biomass $\mathrm{m}^{-2}$, belowground biomass $\mathrm{m}^{-2}$, and BGPP declined equally in State Park and Kees Bayou (Table 2, Fig. 7). The relative difference in BNPP did change significantly over time (Table 2), indicating that the decline in BNPP was more pronounced at State Park. However, the $t$ test was only significant after removing an outlier from the analysis $\left(-125.2 \mathrm{mg} \mathrm{O}_{2} \mathrm{~m}^{-2} \mathrm{~h}^{-1}\right.$ in June 2002, not shown on Fig. 7). Fig. 6 illustrates that detrital biomass $\mathrm{m}^{-2}$ and BR were higher in State Park than in Kees Bayou. The $t$-tests comparing relative differences between sites before and after January 2006

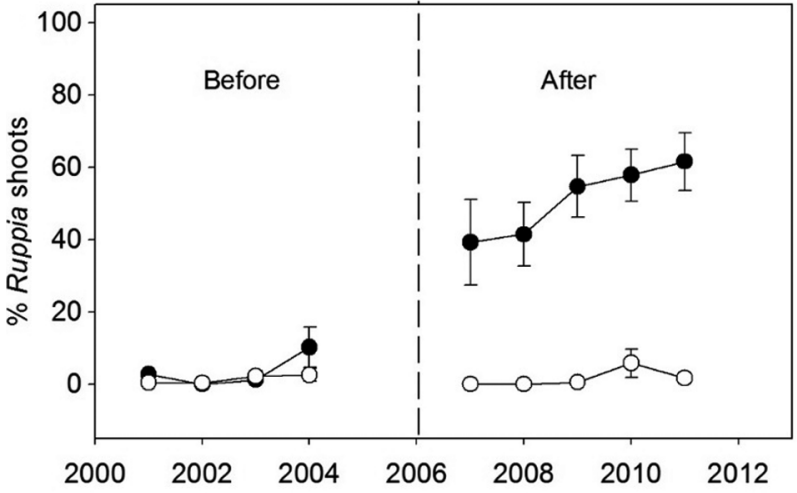

Fig. 5. Change in species composition in State Park (white) and Kees Bayou (black), expressed as the percentage of Ruppia maritima shoots per core sample, averaged per year. Before and after indicate the periods before and after the emergence of $R$. maritima in Kees Bayou. Error bars represent standard error

showed no significant effect for either BR or detritus $\mathrm{m}^{-2}$, but the $\mathrm{p}$-value for detritus $\mathrm{m}^{-2}$ was relatively small ( $p=0.051)$. After January 2006, there was a bigger spread in the differences between the sites for detrital biomass $\mathrm{m}^{-2}$, as indicated by indicated by Fig. 7 (Levene's test: $p=0.006$ ).

\section{DISCUSSION}

Changes in seagrass species composition can alter the role of seagrass beds in coastal ecosystems. Dif- 

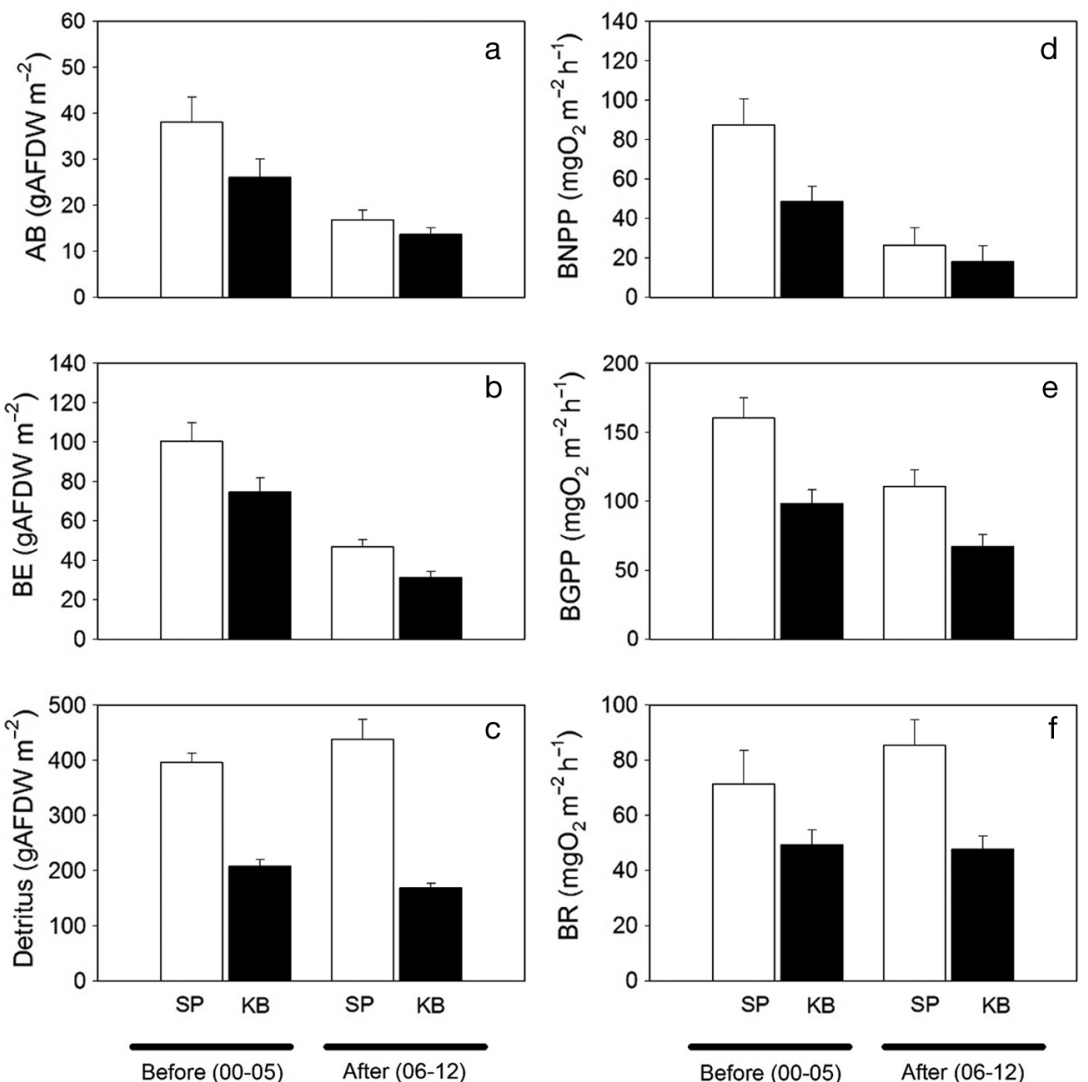

Fig. 6. Changes in (a) aboveground biomass (AB), (b) belowground biomass (BE), (c) detritus, (d) benthic net primary production (BNPP), (e) benthic gross primary production (BGPP), and (f) benthic respiration (BR) in State Park (white) and Kees Bayou (black), before (years 2000-2005) and after (2006-2012) the shift in species composition in Kees Bayou. Error bars represent standard error

ferent seagrass species have different morphology and growth rates, which influence the amount of food and shelter available to epifauna and fish communities associated with seagrass beds (Hyndes et al.
2003, Micheli et al. 2008, Ray et al. 2014). Differences in growth rates, above/ belowground biomass ratios, and leaf turnover rates have the potential to influence herbivory (Cebrian \& Duarte 1998), accumulation of refractory detritus (Cebrian et al. 1997), and the export of organic matter from seagrass beds to adjacent ecosystems (Mateo et al. 2006). Nevertheless, our data indicate that certain seagrasses may be functionally equivalent. The comparison of structural and functional attributes of seagrass beds in State Park and Kees Bayou suggests that the substitution of Halodule wrightii by Ruppia maritima in Kees Bayou had little impact on ecosystem services.

Aboveground biomass $\mathrm{m}^{-2}$ and belowground biomass $\mathrm{m}^{-2}$ declined equally in both sites, so we cannot attribute the decline to the change in species composition in Kees Bayou. It is more likely that both sites were impacted by an external factor, such as changes in environmental drivers or an increase in nutrient load. The overall lower seagrass biomass $\mathrm{m}^{-2}$ in Kees Bayou was probably due to different site characteristics, such as sediment composition or flushing rate. These factors can affect seagrass growth through changes in nutrient availability and sediment sulfide concentrations (Valiela et al. 1997, de Boer 2007). It is somewhat surprising that the emergence of $R$. maritima did not have a stronger impact on seagrass biomass $\mathrm{m}^{-2}$, as $R$. maritima and $H$. wrightii have different life strate-

Table 1. Average, standard error and sample size for biomass, detritus and metabolism of all sample events in each lagoon from 2000-2005 and 2006-2012

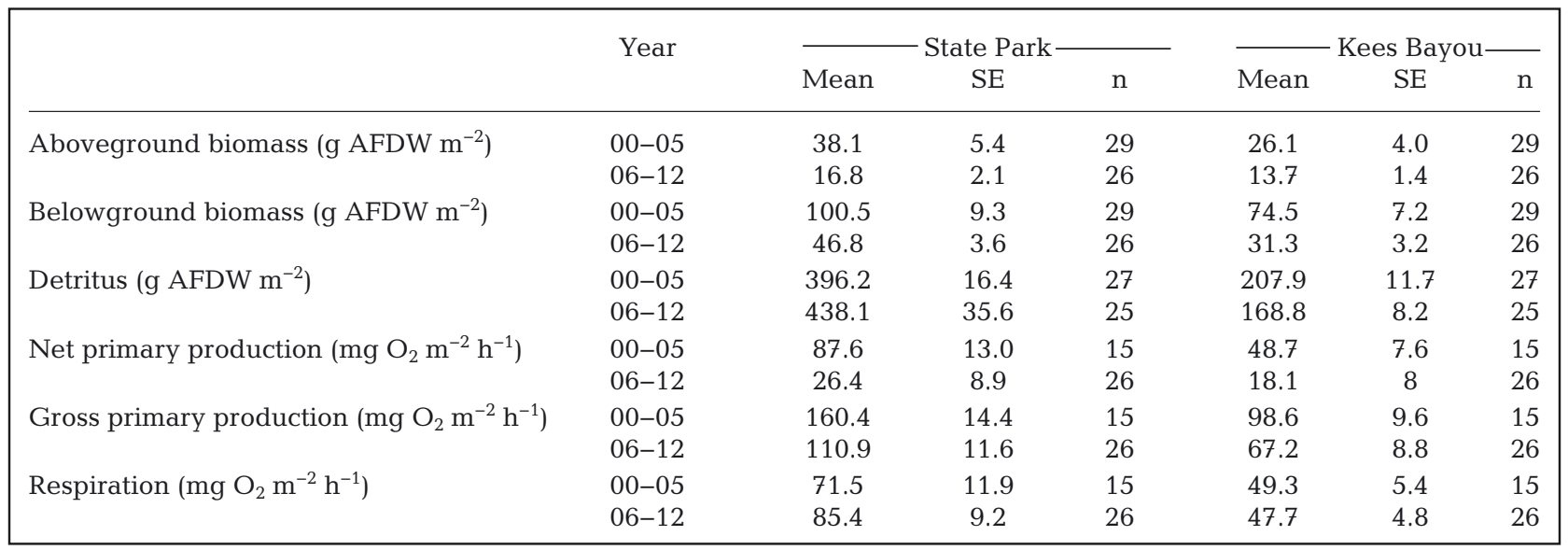


Table 2. Welch's 2-sample $t$-test comparing the paired differences between the sites for aboveground biomass (AB), belowground biomass (BE), detritus (DET), benthic net primary production (BNPP), benthic gross primary production (BGPP), and benthic respiration (BR) between 2000-2005 and 2006-2012. AB and BR were log transformed to meet the assumption of additivity. SP: State Park; KB: Kees Bayou. ${ }^{*}$ p $<0.05$ (changes are considered significant)

\begin{tabular}{|lccl|}
\hline Variable & df & $t$ & $\mathrm{p}$ \\
\hline $\log (\mathrm{SP} \mathrm{AB})-\log (\mathrm{KB} \mathrm{AB})$ & 52 & 1.35 & 0.181 \\
SP BE - KB BE & 48 & 1.25 & 0.216 \\
SP DET - KB DET & 33 & 2.02 & 0.051 \\
SP BNPP - KB BNPP & 19 & 1.54 & 0.140 \\
SP BNPP - KB BNPP (outlier removed) & 20 & 2.5 & $0.021^{*}$ \\
SP BGPP - KB GPP & 18 & 0.87 & 0.398 \\
$\log ($ SP BR $)-\log ($ KB BR $)$ & 28 & 0.36 & 0.724 \\
\hline
\end{tabular}

gies. In monotypic beds of $H$. wrightii, the biomass of roots and rhizomes, averaged over a growth cycle, typically comprises 55 to $86 \%$ of the total biomass on a per $\mathrm{m}^{2}$ basis (Table 3 ). In mixed beds and in monotypic $R$. maritima beds, these values tend to be a lot lower: annual averages of belowground biomass range between 23 and $65 \%$ of total biomass (Table 3 ). The contribution of belowground biomass to total biomass did not differ much between the monotypic seagrass bed in State Park and the mixed seagrass bed in Kees Bayou: between 2006 and 2012, belowground biomass comprised approximately $74 \%$ of the total biomass in State Park and $68 \%$ in Kees Bayou. The lack of a strong
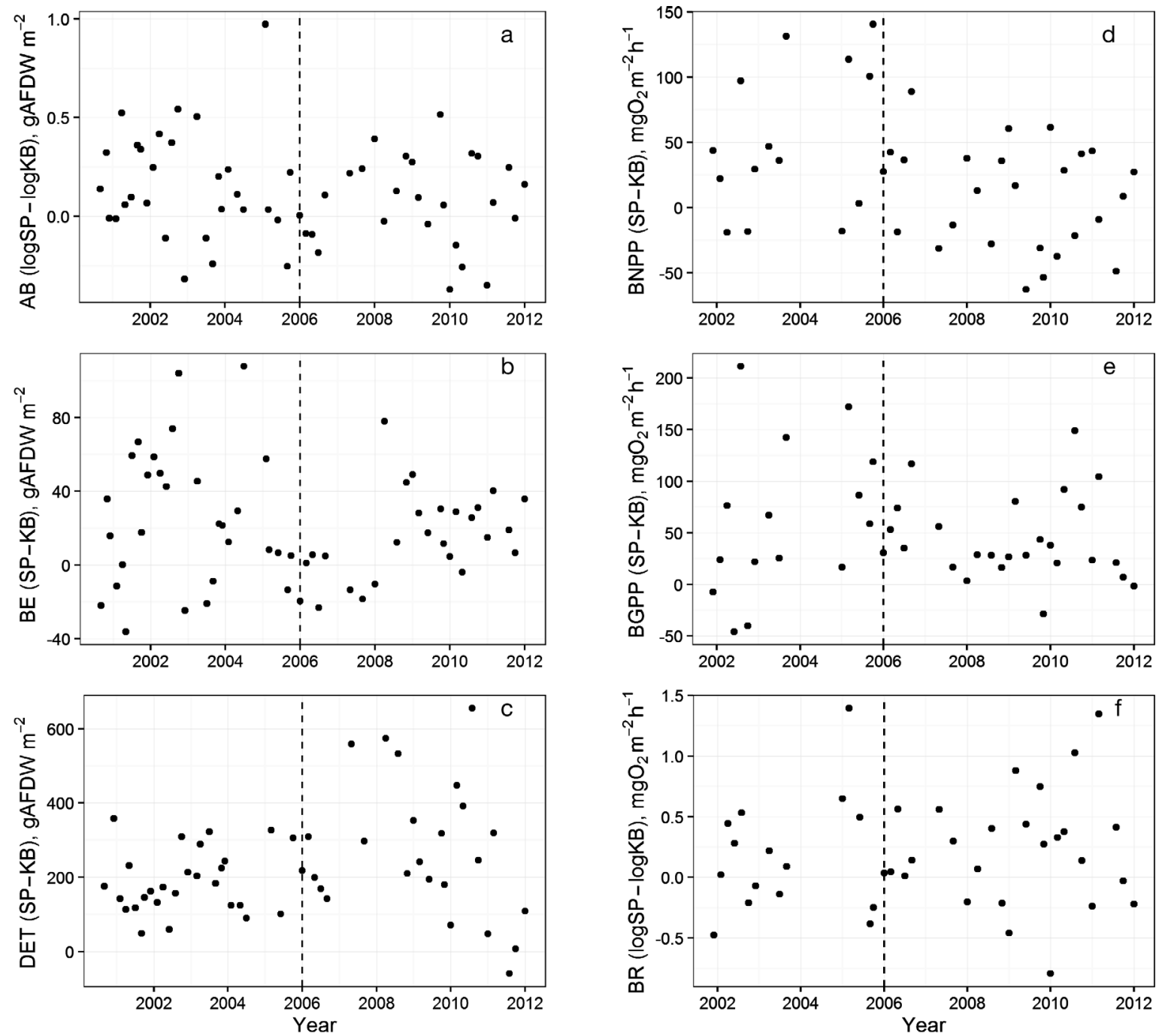

Fig. 7. Paired differences between State Park SP and Kees Bayou KB for (a) log mean aboveground biomass (AB), (b) belowground biomass (BE), (c) detritus (DET), (d) benthic net primary production (BNPP), (e) benthic gross primary production (BGPP), and (f) $\log$ benthic respiration (BR) 


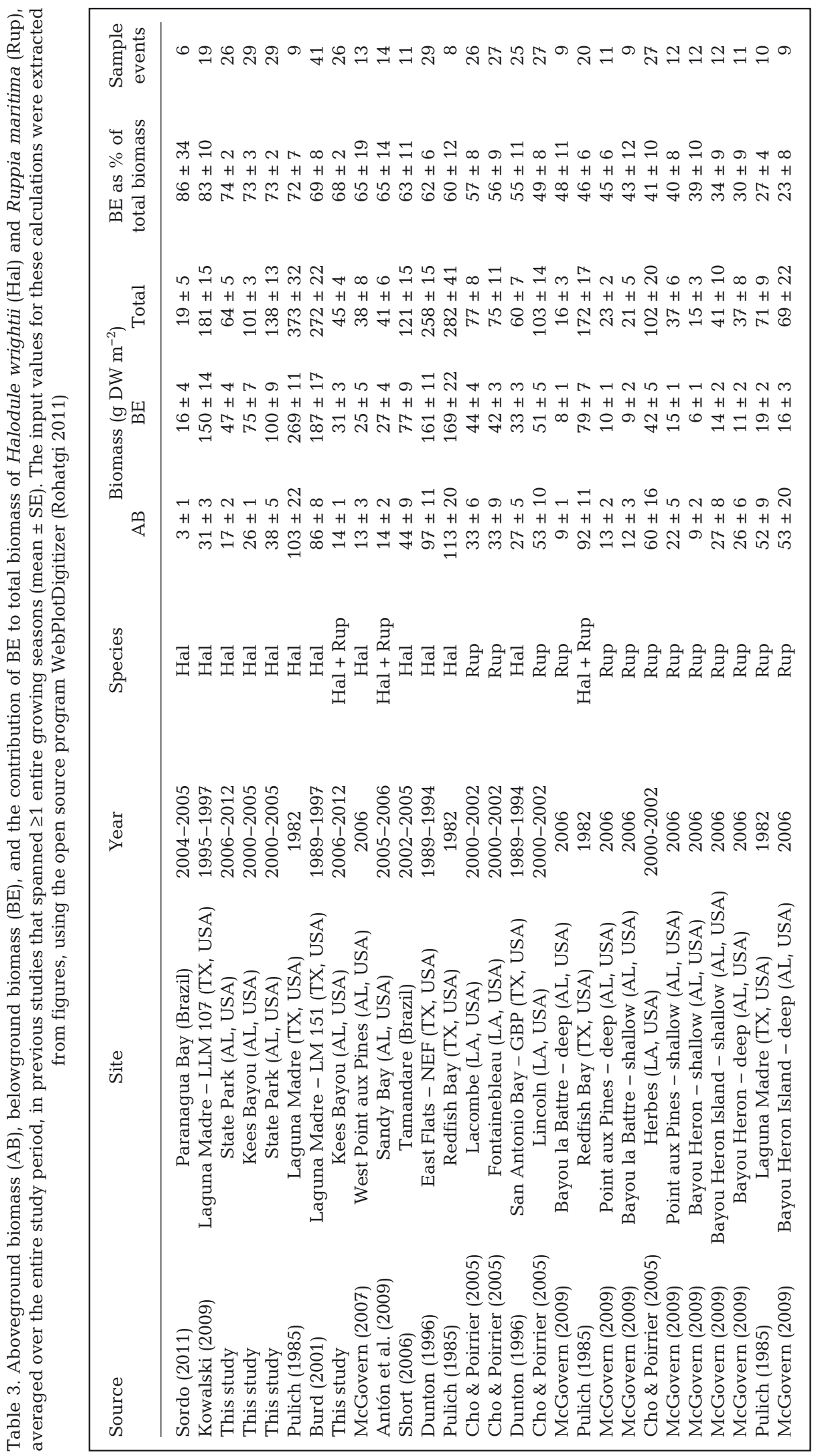

effect of the introduction of $R$. maritima on aboveground and belowground biomass $\mathrm{m}^{-2}$ could be related to environmental conditions in our sites. After January 2006, the total seagrass biomass $\mathrm{m}^{-2}$ in State Park and Kees Bayou was relatively low compared to other $H$. wrightii and $R$. maritima beds along the Gulf of Mexico (Table 3), indicating that both seagrass beds were growing in suboptimal conditions.

Net ecosystem metabolism is the net effect of production and respiration for all biological components in an ecosystem. A positive value indicates that the system is autotrophic, which means that the combined photosynthesis rate of all biological components exceeds the community respiration rate. A negative value is an indicator of a heterotrophic system, where community respiration exceeds in situ primary production (Smith \& Hollibaugh 1997, Caffrey 2004). Our measurements of benthic net ecosystem metabolism are based on in situ daytime incubations, under standardized conditions $(<10 \%$ cloud cover, incubations over solar noon), and as such, they cannot be used to accurately determine the trophic status of the seagrass beds. Another caveat is that we do not have measurements of seagrass biomass within the metabolism incubation chambers, so we cannot link measurements from individual chambers to the biomass of primary producers enclosed. However, our metabolism data can be used to compare values among lagoons and over time.

There was no significant change in relative differences 
in BGPP between the lagoons before and after January 2006. However, our data indicate that the decline in BNPP was bigger in State Park than in Kees Bayou. The similarity between average seagrass biomass and average primary production suggests that the lower values after January 2006 are the result of an overall decline in photosynthetic biomass. Between 2006 and 2012, BGPP in seagrass beds in State Park and Kees Bayou was relatively low compared to values from other studies with similar methods (Murray \& Wetzel 1987, Ziegler \& Benner 1998, Antón et al. 2009). This further strengthens the hypothesis that both seagrass beds were growing in suboptimal conditions.

$\mathrm{BR}$ and detrital biomass $\mathrm{m}^{-2}$ followed a different trajectory compared to seagrass biomass and primary production. This suggests that a significant fraction of the dead organic matter in the sediment was coming from external sources, such as the surrounding marshes and the seagrass beds outside the lagoons. This is not surprising, as $R$. maritima and $H$. wrightii are both fast-growing seagrass species with high leaf turnover rates (Kantrud 1991, Virnstein 1982). Such species often have small pools of refractory detritus because they lose a large fraction of their production to herbivory and recycle most of their residual detrital production (Cebrian et al. 1997, Cebrian \& Duarte 1998).

The total amount of seagrass habitat increased after the emergence of $R$. maritima in Kees Bayou, as the area of the bed increased from $10.7 \%$ to $48.2 \%$ of the lagoon surface between 2004 and 2012. This change could have influenced the overall food web within the lagoon, as infaunal and epifaunal communities often differ between seagrass beds and adjacent bare sediments (Orth et al. 1984, FerreroVicente et al. 2011). However, a separate study comparing fish, macroinvertebrate, and epifaunal communities found little difference between Kees Bayou, State Park, and 4 other nearby lagoons with varying levels of seagrass cover (McDonald et al. 2016). This could be attributed to habitat redundancy between seagrass beds and fringing marshes or to the shallow depth of these lagoons, which limits access for large predators (McDonald et al. 2016).

\section{CONCLUSION}

A shift between 2 early successional seagrass species with similar morphology had little impact on the ecosystem services of seagrass beds in 2 shallow coastal lagoons. The partial replacement of Halodule wrightii by Ruppia maritima did not alter biomass $\mathrm{m}^{-2}$, detritus $\mathrm{m}^{-2}$, BGPP, or BR. However, there was a small positive effect on BNPP. In addition, the emergence of $R$. maritima increased the amount of available habitat through rapid expansion. The small differences in seagrass biomass and metabolism indicate that $R$. maritima provided similar habitat as $H$. wrightii. This pattern suggests that changes in the dominant seagrass species do not always have a large effect on ecosystem services provided by seagrass beds. Despite their different life strategies, $H$. wrightii and $R$. maritima may be functionally equivalent when growing in suboptimal conditions.

Acknowledgements. We thank the many graduate students and interns who helped with data collection, in particular Jason Stutes, Ashley McDonald, Loren Marino, Sara Smith, Eric Sparks, and Shailesh Sharma. The NOAA National Coastal Data Development Center (NCDDC) and Northern Gulf Institute provided funding for this work. B.C. was supported with a graduate fellowship from the Department of Marine Sciences (University of South Alabama) and grants from NCDDC. Finally, we would like to thank the handling editor and 4 anonymous reviewers for their advice and helpful suggestions.

\section{LITERATURE CITED}

Adair SE, Moore JL, Onuf CP (1994) Distribution and status of submerged vegetation in estuaries of the upper Texas coast. Wetlands 14:110-121

Agami M, Waisel Y (1988) The role of fish in distribution and germination of seeds of the submerged macrophytes Najas marina L. and Ruppia maritima L. Oecologia 76: 83-88

Antón A, Cebrian J, Duarte CM, Heck KL Jr, Goff J (2009) Low impact of Hurricane Katrina on seagrass community structure and functioning in the northern Gulf of Mexico. Bull Mar Sci 85:45-59

Antón A, Cebrian J, Heck KL, Duarte CM, Sheehan KL, Miller MEC, Foster CD (2011) Decoupled effects (positive to negative) of nutrient enrichment on ecosystem services. Ecol Appl 21:991-1009

Bonis A, Lepart J, Grillas P (1995) Seed bank dynamics and coexistence of annual macrophytes in a temporary and variable habitat. Oikos 74:81-92

Burd AB, Dunton KH (2001) Field verification of a lightdriven model of biomass changes in the seagrass Halodule wrightii. Mar Ecol Prog Ser 209:85-98

> Burkholder JM, Tomasko DA, Touchette BW (2007) Seagrasses and eutrophication. J Exp Mar Biol Ecol 350: 46-72

> Caffrey JM (2004) Factors controlling net ecosystem metabolism in U.S. estuaries. Estuaries 27:90-101

Cebrián J, Duarte CM (1998) Patterns in leaf herbivory on seagrasses. Aquat Bot 60:67-82

Cebrián J, Duarte CM, Marbà N, Enríquez S (1997) Magnitude and fate of the production of four co-occurring Western Mediterranean seagrass species. Mar Ecol Prog Ser 155:29-44 
Cebrian J, Foster CD, Plutchak R, Sheehan KL and others (2008) The impact of Hurricane Ivan on the primary productivity and metabolism of marsh tidal creeks in the North Central Gulf of Mexico. Aquat Ecol 42:391-404

> Cebrian J, Corcoran AA, Stutes AL, Stutes JP, Pennock JR (2009) Effects of ultraviolet-B radiation and nutrient enrichment on the productivity of benthic microalgae in shallow coastal lagoons of the North Central Gulf of Mexico. J Exp Mar Biol Ecol 372:9-21

> Charalambidou I, Santamaria L, Langevoord O (2003) Effect of ingestion by five avian dispersers on the retention time, retrieval and germination of Ruppia maritima seeds. Funct Ecol 17:747-753

Cho HJ, Poirrier MA (2005) Seasonal growth and reproduction of Ruppia maritima L. s.l. in Lake Pontchartrain, Louisiana, USA. Aquat Bot 81:37-49

Cho HJ, Biber P, Nica C (2009) The rise of Ruppia in seagrass beds: changes in coastal environment and research needs. In: Drury EK, Pridgen TS (eds) Handbook on environmental quality. Nova Science Publ, New York, NY, p 1-15

de Boer WF (2007) Seagrass-sediment interactions, positive feedbacks and critical thresholds for occurrence: a review. Hydrobiologia 591:5-24

> Doering PH, Chamberlain RH, Haunert DE (2002) Using submerged aquatic vegetation to establish minimum and maximum freshwater inflows to the Caloosahatchee estuary, Florida. Estuaries 25:1343-1354

Duarte CM (1991) Allometric scaling of seagrass form and productivity. Mar Ecol Prog Ser 77:289-300

> Dunton KH (1990) Production ecology of Ruppia maritima L. s.l. and Halodule wrightii Aschers, in two subtropical estuaries. J Exp Mar Biol Ecol 143:147-164

Dunton KH (1996) Photosynthetic production and biomass of the subtropical seagrass Halodule wrightii along an estuarine gradient. Estuaries 19:436-447

Ferrero-Vicente LM, Martinez-Garcia E, Cebrián J, Heck KL, Christiaen B, Sanchez Lizaso JL (2011) Comparison of macrobenthic assemblages in shallow coastal lagoons (Northwest Florida) with different levels of anthropogenic impact. Gulf Mex Sci 29:68-73

Fourqurean JW, Powell GVN, Kenworthy WJ, Zieman JC (1995) The effects of long-term manipulation of nutrient supply on competition between the seagrasses Thalassia testudinum and competition in Florida Bay Halodule wrightii. Oikos 72:349-358

Fourqurean JW, Duarte CM, Kennedy H, Marba N and others (2012) Seagrass ecosystems as a globally significant carbon stock. Nat Geosci 5:505-509

González-Correa JM, Bayle JT, Sánchez-Lizaso JL, Valle C, Sánchez-Jerez P, Ruiz JM (2005) Recovery of deep Posidonia oceanica meadows degraded by trawling. J Exp Mar Biol Ecol 320:65-76

Herbert DA, Fourqurean JW (2008) Ecosystem structure and function still altered two decades after short-term fertilization of a seagrass meadow. Ecosystems 11:688-700

Herbert DA, Perry WB, Cosby BJ, Fourqurean JW (2011) Projected reorganization of Florida Bay seagrass communities in response to the increased freshwater inflow of Everglades restoration. Estuaries Coasts 34:973-992

Hyndes G, Kendrick A, MacArthur L, Stewart E (2003) Differences in the species-and size-composition of fish assemblages in three distinct seagrass habitats with differing plant and meadow structure. Mar Biol 142: 1195-1206
Johnson MR, Williams SL, Lieberman CH, Solbak A (2003) Changes in the abundance of the seagrasses Zostera marina L. (eelgrass) and Ruppia maritima L. (widgeongrass) in San Diego, California, following an El Niño event. Estuaries 26:106-115

Kantrud HA (1991) Wigeongrass (Ruppia maritima): a literature review. Fish Wildl Res 10:0-58

Kilminster K, McMahon K, Waycott M, Kendrick GA and others (2015) Unravelling complexity in seagrass systems for management: Australia as a microcosm. Sci Total Environ 534:97-109

Kowalski JL, DeYou HR, Allison TC (2009) Seasonal production and biomass of the seagrass, Halodule wrightii Aschers. (Shoal Grass), in a subtropical Texas lagoon. Estuar Coasts 32:467-482

Koch MS, Schopmeyer SA, Kyhn-Hansen C, Madden CJ, Peters JS (2007) Tropical seagrass species tolerance to hypersalinity stress. Aquat Bot 86:14-24

Lopez-Calderon J, Riosmena-Rodriguez R, Rodriguez-Baron JM, Carrion-Cortez J and others (2010) Outstanding appearance of Ruppia maritima along Baja California Sur, Mexico and its influence in trophic networks. Mar Biodivers 40:293-300

Mateo MA, Cebrián J, Dunton K, Mutchler T (2006) Carbon flux in seagrass ecosystems. In: Larkum ADW, Orth RJ, Duarte CM (eds) Seagrasses: biology, ecology and conservation. Springer, Dordrecht, p 159-192

> McDonald RB, Moody RM, Heck KL, Cebrián J (2016) Fish, macroinvertebrate and epifaunal communities in shallow coastal lagoons with varying seagrass cover of the Northern Gulf of Mexico. Estuaries Coasts 39:718-730

McGovern TM, Blankenhorn K (2007) Observation of fruit production by the seagrass Halodule wrightii in the northeastern Gulf of Mexico. Aquat Bot 87:247-250

McGovern TM (2009) Growth and reproduction of Ruppia maritima in the northern Gulf of Mexico. Gulf Mex Sci 27:91-101

> Micheli F, Bishop MJ, Peterson CH, Rivera J (2008) Alteration of seagrass species composition and function over two decades. Ecol Monogr 78:225-244

> Montague CL, Ley JA (1993) A possible effect of salinity fluctuation on abundance of benthic vegetation and associated fauna in northeastern Florida Bay. Estuaries 16:703-717

Moore KA, Shields EC, Parrish DB (2013) Impacts of varying estuarine temperature and light conditions on Zostera marina (Eelgrass) and its interactions with Ruppia maritima (Widgeongrass). Estuaries Coasts 37:20-30

Murray L, Wetzel RL (1987) Oxygen production and consumption associated with the major autotrophic components in two temperate seagrass communities. Mar Ecol Prog Ser 38:231-239

> Orth RJ, Heck KL, Van Monfrans J (1984) Faunal communities in seagrass beds: a review of the influence of plant structure and prey characteristics on predator-prey relationships. Estuaries 7:339-350

Peterson BJ, Rose CD, Rutten LM, Fourqurean JW (2002) Disturbance and recovery following catastrophic grazing: studies of a successional chronosequence in a seagrass bed. Oikos 97:361-370

Provancha JA, Scheidt DM (2000) Long-term trends in seagrass beds in the Mosquito Lagoon and Northern Banana River, Florida. In: Bortone S.A. (ed) Seagrasses: monitoring, ecology, physiology and management. CRC Press, Bocca Raton, FL, p 177-193 
Pulich WM Jr (1985) Seasonal growth dynamics of Ruppia maritima L.s.l. and Halodule wrightii aschers in Southern Texas and evaluation of sediment fertility status. Aquat Bot 23:53-66

Quammen ML, Onuf CP (1993) Laguna Madre: seagrass changes continue decades after salinity reduction. Estuaries 16:302-310

Ray BR, Johnson MW, Cammarata K, Smee DL (2014) Changes in seagrass species composition in Northwestern Gulf of Mexico estuaries: effects on associated seagrass fauna. PLOS ONE 9:e107751

Rohatgi A (2011) 'WebPlotDigitizer.' http://arohatgi.info/ WebPlotDigitizer/

Sargent FJ, Leary TJ, Crewz DW, Kruer CR (1995) Scarring of Florida's seagrasses: assessment and management options. FMRI Tech. Rep. TR-1. Florida Marine Research Institute, St. Petersburg, FL

Short FT, Koch EW, Creed JC, Magalhaes KM, Fernandez E, Gaeckle JL (2006) SeagrassNet monitoring across the Americas: case studies of seagrass decline. Mar Ecol 27:277-289

Smith SV, Hollibaugh JT (1997) Annual cycle and interannual variability of ecosystem metabolism in a temperate climate embayment. Ecol Monogr 67:509-533

Sordo L, Fournier J, de Oliveira VM, Gern F, de Castro

Editorial responsibility: Morten Pedersen, Roskilde, Denmark
Panizza A, da Cunha Lana P (2011) Temporal variations in morphology and biomass of vulnerable Halodule wrightii meadows at their southernmost distribution limit in the southwestern Atlantic. Bot Mar 54:13-21

Stewart-Oaten A, Murdoch WW, Parker KR (1986) Environmental impact assessment: pseudo-replication in time? Ecology 67:929-940

Stutes J, Cebrián J, Stutes AL, Hunter A, Corcoran AA (2007) Benthic metabolism across a gradient of anthropogenic impact in three shallow coastal lagoons in NW Florida. Mar Ecol Prog Ser 348:55-70

Valiela I, McClelland J, Hauxwell J, Behr PJ, Hersh D, Foreman K (1997) Macroalgal blooms in shallow estuaries: controls and ecophysiological and ecosystem consequences. Limnol Oceanogr 42:1105-1118

Virnstein RW (1982) Leaf growth rate of the seagrass Halodule wrightii photographically measured in situ. Aquat Bot 12:209-218

Waycott M, Duarte CM, Carruthers TJB, Orth RJ and others (2009) Accelerating loss of seagrasses across the globe threatens coastal ecosystems. Proc Natl Acad Sci USA 106:12377-12381

Ziegler S, Benner R (1998) Ecosystem metabolism in a subtropical seagrass-dominated lagoon. Mar Ecol Prog Ser 173:1-12

Submitted: May 13, 2014; Accepted: July 26, 2016 Proofs received from author(s): September 7, 2016 